INSTITUTE OF FORESTRY • BELGRADE

INSTITUT ZA ŠUMARSTVO • BEOGRAD

SUST AINABLE FORESTRY

COLLECTION 71-72, 2015
ODRŽIVO ŠUMARSTVO

ZBORNIK RADOVA 71-72, 2015

UDK $630 * 453: 595.768 .1(497.11-11)=111$

Original scientific paper

\title{
IMPACT OF EXTREME WEATHER CONDITIONS ON THE POPULATION DYNAMICS OF BARK BEETLES IN THE FORESTS OF EASTERN SERBIA
}

\author{
Mara TABAKOVIĆ-TOŠIĆ, Marija MILOSAVLJEVIĆ
}

\begin{abstract}
The paper presents the results of a one-year study of population dynamics of bark beetles by the method of bark beetle trapping using pheromone traps with the following pheromone dispensers - aggregation pheromones: IAC Ecolure (for Ips acuminatus and I. sexdentatus), IT Ecolure (for I. typographus) and PC Ecolure (for Pityogenes chalcographus), after the ice storm that hit the region of Eastern Serbia, especially the forest estate Timočke šume Boljevac (State enterprise Srbijašume) in November 2014. The population levels of the monitored bark beetle species in the controlled area in 2015 were generally within the limits of normal conditions.
\end{abstract}

Keywords: ice-breaks, Ips typographus, I. acuminatus, I. curvidens, Pityogenes chalcographus, pheromone traps, monitoring

\section{UTICAJ EKSTREMNIH KLIMATSKIH USLOVA NA POPULACIONU DINAMIKU POTKORNJAKA U ŠUMAMA ISTOČNE SRBIJE}

Izvod: U radu su prikazani jednogodišnji rezultati istraživanja populacione dinamike potkornjaka metodom lova pomoću feromonskih klopki uz korišćenje feromonskih dispenzera - agregacionih feromona tipa IAC Ecolure (za Ips acuminatus i I. sexdentatus), IT Ecolure (za I. typographus) i PC Ecolure (za Pityogenes chalcographus), a nakon ledenog talasa koji je zahvatio područje Istočne Srbije, posebno Šumsko gazdinsvo Timočke šume Boljevac (Javno preduzeće Srbijašume), u novembru 2014. godine. Populacioni nivoi posmatranih vrsta potkornjaka u kontrolisanom području u 2015. godini, bili su uglavnom u granicama normalnog stanja.

\footnotetext{
${ }^{1}$ Institute of Forestry, Belgrade, Serbia
} 
Ključne reči: ledolomi, Ips typographus, I. acuminatus, I. curvidens, Pityogenes chalcographus, feromoske klopke, monitoring

\section{INTRODUCTION}

The structure and the relations among their members make forests one of the most complex ecosystems on earth. The stability of forest ecosystems greatly depends on the impact, i.e. presence of different harmful abiotic and biotic factors both at the global and at the local level. At the local level, these factors include plant diseases, economically harmful living organisms, climate factors, local environment pollution, whereas at the global level they refer to the climate change, reflected in the global warming which is the result of the ozone layer depletion.

The climate is regarded as the main ecological abiotic factor and it is inextricably bound to some ecosystems, i.e. their existence depends upon climate, therefore, it is of utmost importance for their development and stability. Climate parameters affect soil fertility, vitality of plants, aggressiveness and pathogenicity of the fungi that inhabit certain tissues of host plants, and population dynamics of so-called "beneficial and harmful" forest insects.

About $90 \%$ of all natural disasters which have occurred since 1980 are directly or indirectly attributed to the weather and climate. About $95 \%$ of the economic losses caused by catastrophic events are the result of climate-related disasters. The annual number of disasters caused by extreme weather and climate in Europe increased by about 65\% over the period 1998-2007 compared to the average annual number for 1980. It is estimated that in the next decades the losses caused by natural disasters will be dominant, and that in the second half of the next century the effects of the climate change on the economy will be more pronounced (Rosenzweig et al., 2001).

A severe ice storm accompanied by heavy rainfall hit the area of central Serbia (State Enterprise Srbijašume: Forest Estates Niš, Timočke šume Boljevac, Južni Kučaj Despotovac, Rasina Kruševac, Severni Kučaj Kučevo; 18,500 ha of state forests) in late November and early December 2014 and caused unprecedented ice breakages in artificially-established conifer stands, mostly of spruce and Austrian pine. The most vulnerable area was the Forest Estate Timočke šume Boljevac with 10,060.72 hectares (Srbijašume estimate: 979,682 $\mathrm{m}^{3}$ of damaged or dead trees).

Spatial and temporal scales of insect outbreaks increase due to dry summers and mild winters at high elevations. In the last decade, intense outbreaks of bark beetles (Coleoptera: Curculionidae, Scolytinae) were recorded on spruce and silver fir trees in the southeast of Europe. Ips typographus (Linnaeus, 1758), distributed throughout the Palearctic region (Weslien, 1992), is mostly a secondary biotic agent, affecting only weakened trees. As a result, it is possible to assess the level of risk of forest infestation for this species according to the combination of environmental traits that are present, and on the management aims. However, I. typographus is currently expanding its range and interestingly, outbreak risks are similarly high outside its natural range as in non-managed old-growth spruce stands. Spruce forests on the territory of southeastern Europe have been heavily 
attacked by I. typographus and Pityogenes chalcographus (Linnaeus, 1761) and Austrian and Scots pine forests have been mostly affected by forest fires followed by outbreaks of Ips sexdentatus (Börner, 1767) and other bark beetles. In Europe, mass propagation of the spruce bark beetle, I. typographus L, following windthrows and drought poses a serious threat to mature spruce forests. Fresh windthrown spruce trees are suitable as brood trees for I. typographus, thereby causing a significant increase of the bark beetle attacks on living spruce trees. This makes I. typographus rank among the major insect pests of European forests. (Christiansen and Bakke, 1988). In Europe, $8 \%$ of the total forest damage between 1850 and 2000 was caused by bark beetles, mainly I. typographus (Jönsson et al., 2007).

Most bark beetles are biologically adapted to the physiological stress of the host, which means that they bore only into physiologically weakened trees. Under suitable circumstance, a small number of species are capable of attacking completely healthy, vital trees and thus becoming primary pests. I. typographus and $P$. chalcographus are known to have the ability of dramatic outbreaks.

\section{MATERIALS AND METHODS}

A great number of methods and procedures for monitoring the population density and studying the qualitative characteristics of bark beetles have been developed. The current trend in this field is the application of various biotechnological methods which control the population density of these organisms and keep them below the risk levels. A revolution was brought about by the discovery of the mechanisms of chemical communication within individual species of bark beetles, i.e. very coherent and uniform, but often complex chemical information transfer and its impact on the behavior of insects. The fact that trees are many times more attractive in the initial stage of bark beetle colonization results from their bioproduction of aggregation pheromones. A lot of synthetic products that are available in the market are actually direct imitations or copies of such substances. Selectivity is one of the key features of these substances i.e. they attract only the members of related species of bark beetles, or even just one specific species. Technological purity of the product usually leads to their restricted biological efficiency. For example, when correctly applied and under ordinary conditions (no competition by large windthrows or by an active attack simultaneously at hundreds of spruce next to a trap line) the complete control system is able to reduce infestation of living spruce by $70-100 \%$ compared to tree mortality where the system is run without traps (Niemeyer, 1997).

The control of I. typographus, I. acuminatus (Gyllenhaal, 1827), I. sexdentatus population density and the ice breakage in the autumn of 2014, in four forest administrations (Zaječer, Negotin, Boljevac, Knjaževac) of the Forest Estate Timočke šume Boljevac was carried out by the method of capturing beetles into specially-designed pheromone traps of Ecotrap type. Monitoring of the number of captured specimens of these species was performed at 15 day intervals from May to September 2015, at the locations listed in Table 1. 
Table 1. Pheromone trap locations

\begin{tabular}{|c|c|c|c|c|}
\hline $\begin{array}{c}\text { Forest } \\
\text { administration }\end{array}$ & Management unit & Compartment & Subcompartment & $\begin{array}{l}\text { Artificially- } \\
\text { established } \\
\text { stand of }\end{array}$ \\
\hline \multirow{8}{*}{ Zaječar } & \multirow{7}{*}{$\begin{array}{c}\text { Šaška - Studena - } \\
\text { Selačka reka }\end{array}$} & 6 & $\mathrm{a}$ & Austrian pine \\
\hline & & 22 & $\mathrm{~b}$ & Austrian pine \\
\hline & & 27 & $\mathrm{a}$ & Austrian pine \\
\hline & & 28 & $\mathrm{c}$ & Austrian pine \\
\hline & & 33 & $\mathrm{a}, \mathrm{g}$ & Austrian pine \\
\hline & & 40 & $\mathrm{c}$ & Austrian pine \\
\hline & & 41 & $\mathrm{a}$ & Austrian pine \\
\hline & $\begin{array}{c}\text { Vrška Čuka - Baba } \\
\text { Jona - Treći Vrh }\end{array}$ & 40 & $\mathrm{j}$ & Austrian pine \\
\hline \multirow{7}{*}{ Negotin } & \multirow{7}{*}{ Deli Jovan 2} & 44 & $\mathrm{c}$ & Austrian pine \\
\hline & & 45 & $\mathrm{~h}$ & Austrian pine \\
\hline & & 47 & $a, b$ & Austrian pine \\
\hline & & 49 & $\mathrm{a}$ & Austrian pine \\
\hline & & 50 & $\mathrm{a}$ & Austrian pine \\
\hline & & 51 & $\mathrm{a}$ & Austrian pine \\
\hline & & 52 & $\mathrm{~b}$ & Austrian pine \\
\hline \multirow{8}{*}{ Boljevac } & Markov Kamen & 9 & $\mathrm{~b}$ & Austrian pine \\
\hline & \multirow{3}{*}{ Bogovina 1} & 88 & $\mathrm{a}, \mathrm{b}$ & spruce \\
\hline & & 87 & $\mathrm{a}, \mathrm{c}, \mathrm{d}, \mathrm{e}, \mathrm{f}$ & spruce \\
\hline & & 32 & $\mathrm{~b}, \mathrm{c}$ & spruce \\
\hline & Južni Kučaj 3 & 76 & $\mathrm{a}$ & spruce \\
\hline & Južni Kučaj 2 & 84 & $\mathrm{c}$ & spruce \\
\hline & Rtanj & 12 & $\mathrm{c}$ & Austrian pine \\
\hline & Čestobrodica & 3 & $\mathrm{~b}$ & Austrian pine \\
\hline \multirow{20}{*}{ Knjaževac } & \multirow{3}{*}{ Tupižnica } & 7 & $a, b$ & $\begin{array}{c}\text { Austrian pine, } \\
\text { spruce }\end{array}$ \\
\hline & & 8 & $\mathrm{a}$ & Austrian pine \\
\hline & & 12 & $\mathrm{~d}$ & spruce \\
\hline & \multirow{8}{*}{ Zaglavak I } & 27 & $a, b$ & Austrian pine \\
\hline & & 40 & $\mathrm{~b}$ & Austrian pine \\
\hline & & 41 & $\mathrm{~b}, \mathrm{c}, \mathrm{g}$ & Austrian pine \\
\hline & & 47 & $\mathrm{a}, \mathrm{d}, \mathrm{e}, \mathrm{h}, \mathrm{i}$ & Austrian pine \\
\hline & & 49 & $\mathrm{~b}$ & Austrian pine \\
\hline & & 96 & $\mathrm{a}$ & Austrian pine \\
\hline & & 97 & $\mathrm{a}$ & Austrian pine \\
\hline & & 98 & $\mathrm{a}, \mathrm{d}, \mathrm{g}, \mathrm{h}$ & Austrian pine \\
\hline & \multirow{6}{*}{ Tresibaba } & 17 & $\mathrm{~b}$ & Austrian pine \\
\hline & & 23 & $\mathrm{a}$ & Austrian pine \\
\hline & & 47 & $\mathrm{c}$ & Austrian pine \\
\hline & & 48 & $\mathrm{a}, \mathrm{b}, \mathrm{c}$ & Austrian pine \\
\hline & & 51 & $\mathrm{~b}, \mathrm{c}$ & Austrian pine \\
\hline & & 52 & $\mathrm{~b}$ & Austrian pine \\
\hline & \multirow{3}{*}{ Zaglavak II } & 24 & $\mathrm{a}$ & Austrian pine \\
\hline & & 25 & $\mathrm{a}, \mathrm{d}$ & Austrian pine \\
\hline & & 26 & $\mathrm{a}$ & Austrian pine \\
\hline
\end{tabular}




\begin{tabular}{|c|c|c|c|c|}
\hline $\begin{array}{c}\text { Forest } \\
\text { administration }\end{array}$ & Management unit & Compartment & Subcompartment & $\begin{array}{c}\text { Artificially- } \\
\text { established } \\
\text { stand of }\end{array}$ \\
\hline \multirow{3}{*}{} & & 26 & $\mathrm{~b}$ & Austrian pine \\
\cline { 3 - 5 } & & 26 & $\mathrm{~d}$ & Austrian pine \\
\cline { 3 - 5 } & & $69 /$ & $\mathrm{d}, \mathrm{e}$ & Austrian pine \\
\cline { 2 - 4 } & & 68 & $\mathrm{~d}$ & Austrian pine \\
\hline
\end{tabular}

\section{RESULTS AND DISCUSSION}

Based on the Directive on the protection and rehabilitation of the forests damaged by ice-breaks and icethrows (Ministry of Agriculture and Environmental Protection - Forest Directorate), in line with the adopted Action Plan (SE Srbijašume), Forest Estate Timočke šume Boljevac set 127 ECOTRAP pheromone traps (Universal unidirectional selective barrier pheromone trap for monitoring and mass trapping of Bark beetles) on the total area of 467.8 ha of conifer forests, using the following pheromone dispensers: IAC Ecolure (for I. acuminatus and I. sexdentatus), IT Ecolure (for $I$. typographus) and PC Ecolure (for $P$. chalcographus). The results of the five-month monitoring are shown in Table 2. 
Table 2. Monitoring of bark beetles in conifer forests damaged by ice-breaks, within the Forest administrations of Boljevac, Zaječar, Knjaževac and Negotin (SE Srbijašume, Forest estate Timočke šume Boljevac) in 2015

\begin{tabular}{|c|c|c|c|c|c|c|c|}
\hline \multirow[b]{2}{*}{$\begin{array}{l}\text { Number of } \\
\text { traps }\end{array}$} & \multirow[b]{2}{*}{$\begin{array}{c}\text { Type of } \\
\text { pheromone }\end{array}$} & \multicolumn{3}{|c|}{ Locality } & \multicolumn{3}{|c|}{ Total number of captured specimens } \\
\hline & & Management unit & $\begin{array}{l}\text { Compartment } \\
\text { subcomp. }\end{array}$ & $\begin{array}{c}\text { The area of the } \\
\text { pheromone effect (ha) }\end{array}$ & $\begin{array}{c}\text { Ips } \\
\text { typographus }\end{array}$ & $\begin{array}{c}\text { Pityogenes } \\
\text { chalcographus }\end{array}$ & $\begin{array}{l}\text { Ips acuminatus } \\
\text { Ips sexdentatus }\end{array}$ \\
\hline \multicolumn{8}{|c|}{ Forest administration Boljevac } \\
\hline 1 & \multirow{4}{*}{$\begin{array}{c}\text { PC } \\
\text { Ecolure }\end{array}$} & \multirow{2}{*}{ Bogovina } & $87 / \mathrm{e}, \mathrm{f}$ & 4.56 & & 242 & \\
\hline 1 & & & $32 / \mathrm{b}, \mathrm{c}$ & 2.18 & & 52 & \\
\hline 1 & & Južni Kučaj III & $76 / \mathrm{a}$ & 2.97 & & 1636 & \\
\hline 2 & & Južni Kučaj II & $84 / \mathrm{c}$ & 3.86 & & $46(20,26)$ & \\
\hline 1 & \multirow[b]{2}{*}{ IAC Ecolure } & Čestobrodica & $3 / \mathrm{b}$ & 4.55 & & 1324 & \\
\hline 2 & & Markov kamen & $9 / b$ & 3.37 & $\begin{array}{c}1472(737 \\
735)\end{array}$ & & \\
\hline 1 & \multirow{4}{*}{$\begin{array}{c}\text { IT } \\
\text { Ecolure }\end{array}$} & \multirow{4}{*}{ Bogovina I } & $88 / \mathrm{a}, \mathrm{b}$ & 4.14 & 683 & & \\
\hline 1 & & & $87 / \mathrm{a}$ & 2.63 & 748 & & \\
\hline 1 & & & $87 / \mathrm{c}$ & 2.03 & 61 & 187 & \\
\hline 1 & & & $87 / \mathrm{d}$ & 5.06 & 67 & 193 & \\
\hline \multicolumn{4}{|c|}{12 traps in total } & 35.35 & 3031 & 3680 & \\
\hline \multicolumn{8}{|c|}{ Forest administration Zaječer } \\
\hline 3 & \multirow{9}{*}{ IAC Ecolure } & \multirow{8}{*}{$\begin{array}{l}\text { Šaška -Studena - } \\
\text { Selačka reka }\end{array}$} & $6 / \mathrm{a}$ & 12.94 & & & $158(44,56,58)$ \\
\hline 5 & & & $22 / \mathrm{b}$ & 19.58 & & & $170(40,38,24,41,27)$ \\
\hline 2 & & & $27 / \mathrm{a}$ & 5.92 & & & $228(114,114)$ \\
\hline 1 & & & $28 / \mathrm{c}$ & 2.05 & & & 83 \\
\hline 5 & & & $33 / \mathrm{a}$ & 21.91 & & & $365(64,49,151,55,46)$ \\
\hline 1 & & & $33 / \mathrm{g}$ & 2.68 & & & 61 \\
\hline 2 & & & $40 / \mathrm{c}$ & 6.15 & & & $126(42,84)$ \\
\hline 2 & & & $41 / \mathrm{a}$ & 6.21 & & & $146(75,71)$ \\
\hline 2 & & $\begin{array}{l}\text { Vrška Čuka - Baba } \\
\text { Jona - Treći Vrh }\end{array}$ & $40 / \mathrm{j}$ & 9.40 & & & $268(161,107)$ \\
\hline \multicolumn{4}{|c|}{22 traps in total } & 86.84 & & & 1605 \\
\hline \multicolumn{8}{|c|}{ Forest administration Knjaževac } \\
\hline 1 & \multirow{2}{*}{ IAC Ecolure } & \multirow[t]{2}{*}{ Zaglavak I } & $27 / \mathrm{a}$ & 2.48 & & & 41 \\
\hline 2 & & & $27 / \mathrm{b}$ & 6.83 & & & $158(81,77)$ \\
\hline
\end{tabular}




\begin{tabular}{|c|c|c|c|c|c|c|c|}
\hline \multirow[b]{2}{*}{$\begin{array}{l}\text { Number of } \\
\text { traps }\end{array}$} & \multirow{24}{*}{$\begin{array}{c}\text { Type of } \\
\text { pheromone }\end{array}$} & \multicolumn{3}{|c|}{ Locality } & \multicolumn{3}{|c|}{ Total number of captured specimens } \\
\hline & & Management unit & $\begin{array}{l}\text { Compartment } \\
\text { subcomp. }\end{array}$ & $\begin{array}{c}\text { The area of the } \\
\text { pheromone effect (ha) }\end{array}$ & $\begin{array}{c}\text { Ips } \\
\text { typographus }\end{array}$ & $\begin{array}{c}\text { Pityogenes } \\
\text { chalcographus }\end{array}$ & $\begin{array}{l}\text { Ips acuminatus } \\
\text { Ips sexdentatus }\end{array}$ \\
\hline 1 & & & $40 / \mathrm{b}$ & 4.99 & & & 141 \\
\hline 2 & & & $41 / \mathrm{b}, \mathrm{c}, \mathrm{g}$ & 10.06 & & & $262(150,112)$ \\
\hline 2 & & & 47/a,d,e,h & 7.76 & & & $212(153,59)$ \\
\hline 1 & & & $49 / \mathrm{b}$ & 4.6 & & & 122 \\
\hline 5 & & & $96 / \mathrm{a}$ & 19.09 & & & $220(23,19,63,63,52)$ \\
\hline 7 & & & $97 / a$ & 26.81 & & & $\begin{array}{c}262(65,30,30,32,41,36, \\
28)\end{array}$ \\
\hline 3 & & & 98/a,d,g,h & 10.69 & & & $117(42,47,28)$ \\
\hline 1 & & & $17 / \mathrm{b}$ & 2.27 & & & 26 \\
\hline 1 & & & $23 / \mathrm{a}$ & 2.43 & & & 38 \\
\hline 1 & & Trocib & $47 / \mathrm{c}$ & 3.51 & & & 65 \\
\hline 2 & & Iresibaba & $48 / \mathrm{a}, \mathrm{b}, \mathrm{c}$ & 7.12 & & & $82(22,60)$ \\
\hline 2 & & & $51 / \mathrm{b}, \mathrm{c}$ & 2.48 & & & $83(61,22)$ \\
\hline 2 & & & $52 / \mathrm{b}$ & 6.83 & & & $87(40,47)$ \\
\hline 4 & & & $24 / \mathrm{a}$ & 15.00 & & & $280(88,82,48,62)$ \\
\hline 6 & & & $25 / \mathrm{a}, \mathrm{d}$ & 24.93 & & & $197(43,22,35,25,29,43)$ \\
\hline 1 & & & $26 / \mathrm{a}$ & 3.29 & & & 39 \\
\hline 2 & & Zaglavak II & $26 / \mathrm{b}$ & 6.23 & & & $59(30,29)$ \\
\hline 3 & & & $26 / \mathrm{d}$ & 12,29 & & & $82(35,30,17)$ \\
\hline 2 & & & $69 / \mathrm{d}, \mathrm{e}$ & 6.47 & & & $40(13,27)$ \\
\hline 2 & & & $68 / \mathrm{d}$ & 9.48 & & & $26(12,14)$ \\
\hline 2 & & & $7 / \mathrm{a}$ & 7.50 & & & $507(86,421)$ \\
\hline 1 & & T & $8 / \mathrm{a}$ & 4.42 & & & 273 \\
\hline 1 & $\mathrm{pC}$ Foclure & I upıznica & $7 / \mathrm{b}$ & 3.76 & & 597 & \\
\hline 1 & PC Ecolure & & $12 / \mathrm{d}$ & 4,08 & & 258 & \\
\hline 60 traps in $t$ & & & & 222.5 & & 855 & 3583 \\
\hline & & & Forest & dministration Negotin & & & \\
\hline 1 & & Deli Jovan II & $45 / \mathrm{h}$ & 3,65 & & & 60 \\
\hline 1 & IAC Ecolure & & $44 / \mathrm{c}$ & 3.64 & & & 365 \\
\hline 3 & & & $47 / \mathrm{a}$ & 11.51 & & & $744(471,149,124)$ \\
\hline
\end{tabular}




\begin{tabular}{|c|c|c|c|c|c|c|c|}
\hline \multirow[b]{2}{*}{$\begin{array}{l}\text { Number of } \\
\text { traps }\end{array}$} & \multirow{7}{*}{$\begin{array}{c}\text { Type of } \\
\text { pheromone }\end{array}$} & \multicolumn{3}{|c|}{ Locality } & \multicolumn{3}{|c|}{ Total number of captured specimens } \\
\hline & & Management unit & $\begin{array}{l}\text { Compartment } \\
\text { subcomp. }\end{array}$ & $\begin{array}{l}\text { The area of the } \\
\text { pheromone effect (ha) }\end{array}$ & $\begin{array}{c}\text { Ips } \\
\text { typographus }\end{array}$ & $\begin{array}{c}\text { Pityogenes } \\
\text { chalcographus }\end{array}$ & $\begin{array}{l}\text { Ips acuminatus } \\
\text { Ips sexdentatus }\end{array}$ \\
\hline 2 & & & $47 / \mathrm{b}$ & 6.76 & & & $161(101,60)$ \\
\hline 7 & & & $49 / \mathrm{a}$ & 26.7 & & & $\begin{array}{c}3985(271,219,475,1424, \\
1226,118,252)\end{array}$ \\
\hline 4 & & & $50 / \mathrm{b}$ & 13.97 & & & $1472(218,499,436,319)$ \\
\hline 6 & & & $51 / \mathrm{a}$ & 21.33 & & & $\begin{array}{c}1247(247,137,378,200 \\
135,150)\end{array}$ \\
\hline 9 & & & $52 / \mathrm{a}$ & 35.55 & & & $\begin{array}{c}3092(297,225,603,579 \\
117,196,559,190,326)\end{array}$ \\
\hline \multicolumn{4}{|c|}{33 traps in total } & 123.11 & & & 11126 \\
\hline
\end{tabular}


Seven traps with PC Ecolure aggregation pheromone - pheromone dispenser captured 2831 imagos of $P$. chalcographus (averagely 404.43 individuals per trap) in 5 months (May-September 2015). The maximum number of captured insects (1,636 adult beetles) was achieved in the Forest Administration Boljevac, management unit Južni Kučaj III, compartment 76/a, and the minimum of 20 individuals in the management unit Južni Kučaj II, compartment $84 / \mathrm{c}$ of the same forest administration. Only four pheromone traps of IT Ecolure type were placed in MU Bogovina I, compartments 87 and 88 (Table 2), and a total of 1,559 beetles of I. typographus (averagely 389.75; maximum capture: 748 in compartment 87/a) and 380 of $P$. chalcographus were captured.

The largest number of traps (116) contained a synthetically produced aggregation pheromone of IAC Ecolure type that primarily attracts I. acuminatus and I. sexdentatus imagos. During the five-month monitoring a total of 16314 individuals, or an average of 140.64 per trap were captured. The maximum capture $[3985(271+219+475+1424+1226+118+252)$ imagos $]$ was achieved in the Forest administration Negotin, management unit Deli Jovan II, compartment 49/a, and the minimum (12) in the forest administration Knjaževac, MU Zaglavak II, compartment 68/d (Table 2, Graph 1).

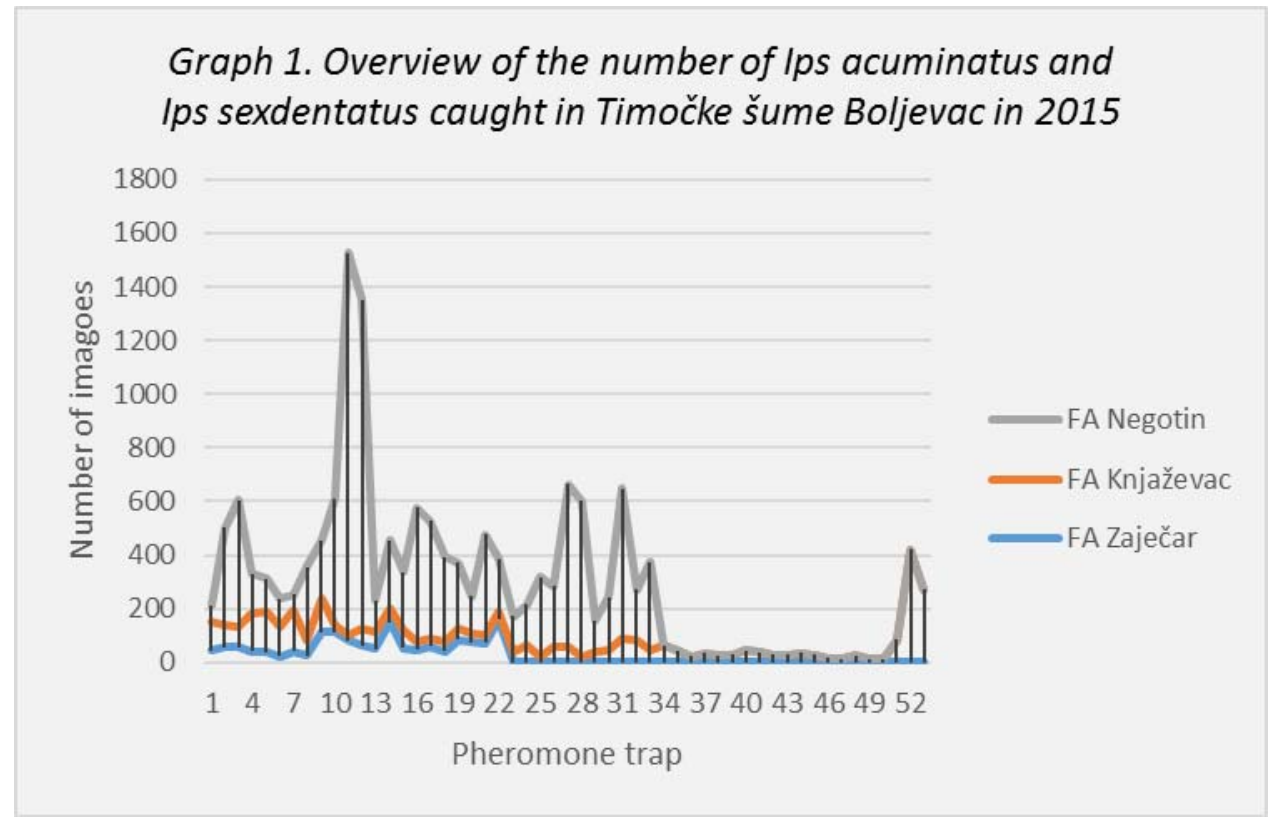

Population levels of the monitored species of bark beetles in the study area in 2015 were generally within the limits of normal conditions. In several compartments of the management units Markov kamen and Bogovina I of the Forest Administration Boljevac, the population density of I. typographus (Table 2) has started to increase but it is still below the critical level. However, this level is likely to be reached in the coming period unless necessary control measures are taken. The situation is the same with $I$. acuminatus and $I$. sexdentatus in 
compartment 49/a, Management unit Deli Jovan II, Forest Administration Negotin (Table 2, Figure 1).

This relatively small number of captured bark beetles could be attributed to several different factors (tall grass around the traps which made them inconspicuous, faults in technology of dispensers, inadequate trap location, trap type (wet or dry), degree of selectivity (simultaneous capture of bark beetle natural enemies - predatory species of Coleoptera and parasitic species of Hymenoptera attracted by the same odours, which in their case act as kairomones, rather than pheromones) (Borden, 1977; Baier, 1994; Lobinger and Feicht, 1998; Pavlin, 1991).

A successful bark beetle attack is accomplished in two steps - firstly, pioneering individuals exhaust the host, then they colonize the whole tree (Lieutier, 2002). Bark beetles are principally attracted by kairomones, but there are various factors that can increase the intensity of the attack. If we apply these scientific facts to the results of this study, it can be concluded that the time between the ice-break and the applied control measures was too short (only a few months) for the previously established populations of the four species of bark beetles to recognize the broken trees as physiologically weakened. In other words, they didn't make a positive correlation (due to negligible or insufficient production of kairomones).

\section{CONCLUSIONS}

The population density of the four of bark beetle species (I. typographus, $I$. acuminatus, $I$. sexdentatus and $P$. chalcographus) in artificially-established conifer stands damaged by ice-breaks in 2014, in the area of forest administrations of Zaječar, Boljevac, Knjaževac and Negotin, on the total surface area of 467.8 ha was managed using 127 traps with specific pheromone dispensers - synthetically produced aggregation pheromones.

The obtained results, with the above-stated exceptions, generally do not indicate an increase in their abundance. However, in the future, weather conditions favourable for their development (mild winters) in the absence of urgent control measures may turn these species into a calamity of bigger proportions.

\section{ACKNOWLEDGEMENTS}

Investigations were carried out within the framework of activities of public interest in the field of harmful organism diagnostics and protection of the health of forest plants on the territory of the Republic of Serbia, excluding the territory of the Autonomous Province of Vojvodina over the period 2015-2019, funded by the Republic of Serbia through the Forest Directorate of the Ministry of Agriculture and Environmental Protection. The authors would particularly like to thank the colleagues from the Head Office of SE Srbijašume and Forest Estate Timočke šume Boljevac on their participation in the performance of the aforementioned tasks on bark beetle monitoring. 


\section{REFERENCES}

Baier, P. (1994): Untersuchungen zur abundanzdynamischen Relevaz der Beifänge von Nemosoma elongatum L. (Col., Ostomidae) in Chalcoprax beköderten Flugbarierfallen für Pityogenes chalcographus L. (Col., Scolytidae). Z. ang. Ent. 117, 51-57.

Borden, J.H. (1977): Behavioral response of Coleoptera to pheromones, allomones and kairomones.U: Chemical Control of Insect Behavior. Editor: H.H. Shorey i J.J. McKelvey, Jr. New York: John Wiley and Sons, 169-198.

Christiansen, E., Bakke, A. (1988): The spruce bark beetle of Eurasia. In: Dynamics of forest insect population: Patterns, Causes, Implications, Ed.: Berryman, A.A., Plenum Press, New York and London, 479-503.

Jönsson et al. (2007): Impact of climate change on the population dynamics of Ips typographus in southern Sweden. Agricultural and forest Meteorology 146: 70-81.

Lieutier, F. (2002): Mechanisms of resistance in conifers and bark beetle attack strategies. In: Wagner, M.R., Clancy, K.M., Lieutier, F., Paine, T.D. (Eds.), Mechanisms and Deployment of Resistance in Trees to Insects, Kluwer Academic Publishers, Dordrecht. 3177.

Lobinger, G., Feicht, E. (1998): Schwärmverhalten und Abundanzdynamik der Erzwespe Karpinskiella pityophtori (Boucek) (Hym., Pteromalidae), eines Parasitoiden des Kupferstechers (Pityogenes chalcographus L., Col., Scolytidae). Anz. Schaedlingskde, Pflantzenschutz, Umweltschutz 72/3, 65-70.

Niemeyer, H. (1997): Integrated bark beetle control: experiences and problems in Northern Germany. In: Proceedings: Integrating cultural tactics into the management of bark beetle and reforestation pests. J.C. Grégoire, A.M. Liebhold, F.M. Stephen, K.R. Day, and S.M. Salom, editors. 1997. Forest Service General Technical Report NE-236: 80-86.

Pavlin, R. (1991): Problem selektivnosti sintetičnih feromonov. Zbornik lesarstva, 38. 126160.

Rosenzweig, C., Iglesias, A., Yang, X.B., Epstein, PR. \& Chivian, E. (2001): Climate change and extreme weather events, Implications for food production, plant diseases, and pests, Global change \& human health, 2(2), 90-104.

Weslien, J. (1992). The arthropod complex associated with Ips typographus (L.) (Coleoptera, Scolytidae): species composition, phenology and impact on bark beetle productivity. Entomol. Fennica 3, 205-213. 